\title{
Occlusal contacts evaluation along orthodontic treatment with clear aligners and
}

\section{fixed appliance}

A valiação dos pontos de contatos oclusais em pacientes tratados com alinhadores e com aparelhos convencionais

Evaluación de puntos de contacto oclusales en pacientes tratados con alineadores y aparatología convencional

\author{
Isabelle Vital Ortiz \\ ORCID: https://orcid.org/0000-0001-9618-5393 \\ Universidade Norte do Paraná, Brazil \\ E-mail: isavital512@gmail.com \\ Paula Vanessa Pedron Oltramari \\ ORCID: https://orcid.org/0000-0002-2285-5179 \\ Universidade Norte do Paraná, Brazil \\ E-mail: pvoltramari@hotmail.com \\ Graziela Hernandes Volpato \\ ORCID: https://orcid.org/0000-0002-8781-145X \\ Universidade Norte do Paraná, Brazil \\ E-mail: grazi.volpato@hotmail.com \\ Thais Maria Freire Fernandes Poleti \\ ORCID: https://orcid.org/0000-0002-4368-8568 \\ Universidade Norte do Paraná, Brazil \\ E-mail: thais.poleti@unopar.br \\ Victor de Miranda Ladewig \\ ORCID: https://orcid.org/0000-0001-6041-1299 \\ Universidade Norte do Paraná, Brazil \\ E-mail: victor@odontobaby.odo.br \\ Ana Claudia de Castro Ferreira Conti \\ ORCID: https://orcid.org/0000-0001-9658-1652 \\ Universidade Norte do Paraná, Brazil \\ E-mail: accfconti@uol.com.br
}

\begin{abstract}
The present research aim was to assess how occlusal contacts change along the initial 6 months of orthodontic treatment with fixed appliance and clear aligners. A sample with 40 patients was divided into 2 groups: Clear Aligners (CA) and Fixed Appliance (FA). In order to register occlusal contacts, patients were posit and instructed about how bite in habitual maximum intercuspidation. Registrations were perfomed monthly along 6 starting treatment months and noted in an occlusogram. A parametric test was applied to evaluate data since it presented a normal distribution according to Shapiro-Wilk test. For inter- and intergroup data analysis the Anova test was performed with a 5\% significance level. Statistical tests were executed on Jamovi software (Jamovi Stats, Version1.2, Sydeney, Australia). There was a reduction in the amount of occlusal contacts for indivduals from both groups, CA and FA. Such reduction was more significative in the 3 starting months for FA group and between $3^{\text {rd }}$ and $4^{\text {th }}$ months for CA group. Therefore, the sort orthodontic appliance had no significant influence over occlusal contacts.
\end{abstract}

Keywords: Dental occlusion; Occlusal adjustment; Clear aligners.

\section{Resumo}

Esse estudo objetivou avaliar as modificações que ocorrem, ao longo de 6 meses de tratamento ortodôntico, nos pontos de contatos em pacientes em tratamento com aparelhos fixos e alinhadores. A mostra foi constituída por 40 participantes divididos de modo aleatório simples em dois grupos: alinhadores (CAT) e aparelho fixo (AF). Para o registro dos contatos oclusais, os pacientes foram posicionados e orientados a realizar a máxima intercuspidação habitual com intensidade máxima. Os registros obtidos mensalmente durante os 6 primeiros meses de tratamento foram copiados em um oclusograma para avaliação. Foi aplicado teste paramétrico para analisar os dados uma vez que apresentaram distribuição normal de acordo com o teste de Shapiro-wilk. Os dados para as análises intragrupos e intergrupos foram analisados por meio do teste Anova, sendo adotado um nível de significância de 5\%. Os testes estatísticos foram executados por meio do programa Jamovi (Jamovi Stats, Versão 1.2, Sydney, Austrália). Tanto para os indivíduos do grupo CAT quanto do grupo AF, houve redução na quantidade de pontos de contatos, sendo esta redução mais significativa nos 3 primeiros meses para os tratamentos com aparelho fixo e entre os meses 3 e 4 para os 
indivíduos com alinhadores estéticos. Dessa forma, pode-se concluir que o tipo de aparelho ortodôntico utilizado no tratamento não influencia de maneira significante no comportamento dos pontos de contatos oclusais.

Palavras-chave: Oclusão dentária; Ajuste oclusal; Alinhadores transparentes.

\section{Resumen}

Este estudio tuvo como objetivo evaluar los cambios que se producen, a lo largo de 6 meses de tratamiento de ortodoncia, en los puntos de contacto en pacientes sometidos a tratamiento con aparatos fijos y alineadores. La muestra estuvo formada por 40 participantes divididos de forma aleatoria simple en dos grupos: alineadores (CAT) y aparato fijo (AF). Para registrar los contactos oclusales, se colocó a los pacientes y se les indicó que realizaran la máxima intercuspidación habitual con la máxima intensidad. Los registros obtenidos mensualmente durante los primeros 6 meses de tratamiento se copiaron en un oclusograma para su evaluación. Se aplicó prueba paramétrica para analizar los datos por presentar distribución normal según la prueba de Shapiro-Wilk. Los datos para los análisis intragrupales e intergrupales se analizaron mediante la prueba de Anova, adoptando un nivel de significancia del 5\%. Las pruebas estadísticas se realizaron utilizando el programa Jamovi (Jamovi Stats, Versión 1.2, Sydney, Australia). Tanto para los individuos de los grupos CAT como AF, hubo una reducción en el número de puntos de contacto, siendo esta reducción más significativa en los primeros 3 meses para los tratamientos con aparatología fija y entre los meses 3 y 4 para los individuos con alineadores estéticos. Así, se puede concluir que el tipo de aparato de ortodoncia utilizado en el tratamiento no influye significativamente en el comportamiento de los puntos de contacto oclusales.

Palabras clave: Oclusión dental; Ajuste oclusal; Alineadores transparentes.

\section{Introduction}

The goal of Orthodontics is to achieve a functional and balanced occlusion, besides esthetics. Although this goal has been the same since the emergence of the specialty, the concepts that define a balanced and functional occlusion have been changed over the years. Maybe the most popular, and even revolutionary, has been the Angle classification. According to the author, the mesiobuccal cusp of the upper first molar must occlude in the central groove of the lower first molar. Despite its importance, this concept has tied orthodontics to the achievement of an anteroposterior relationship in the molar region as the great treatment goal (Angle, 1899; Oltramari et al., 2007).

Some years later, Andrews expanded this concept by setting new goals. Undoubtedly, the paper published in 1972 by the author was a major milestone for orthodontists who then, besides the anteroposterior relationship, also sought an adequate positioning between the anterior teeth, even considering aspects as the curve of Spee (Andrews, 1972).

However, the reference of functional occlusion was only established in the study of Roth (Roth, 1976) in 1972. Besides determining the relationship between teeth during function, the author proposed that there must be contacts between opponent teeth, when in maximum intercuspation there is a distance of $5 \times 10^{-4}$ inches. Also, the greater the number of contacts between teeth, the more balanced the individual's occlusion would be (Haydar, Cier \& Saatçi, 1992; Watanabe-Kanno \& Abrão, 2012).

With this goal in mind, orthodontic treatments began to seek this distribution of contacts. Thus, it became fundamental to assess the interarch relationship at completion of orthodontic treatment. In this sense, fixed appliances always showed great results, obtaining well-distributed and functional occlusal contacts. With the aid of intermaxillary elastics, the intercuspation treatment stage allowed this balance before removing the orthodontic appliance (Oltramari et al., 2007; Lim et al, 2014).

However, over the last few years, there has been a growing concern of the population regarding esthetics. Thus, new types of orthodontic treatment are becoming more popular every day, bringing alternatives that not only meet this demand for more esthetically attractive treatments, but also aim to optimize the treatment time and minimize possible common complications with the use of conventional brackets, such as the risk of caries, accumulation of food remnants, breakage of brackets, among others (Djeu, Shelton \& Maganzini, 2005; Azazipour et al, 2015).

Orthodontic aligners are among the options most desired by patients seeking a more esthetic orthodontic 
treatment. This treatment modality consists of transparent plates that, by a staging system, promote the gradual correction of tooth positioning. However, it is questioned whether the quality of orthodontic treatment with this system is the same when compared to fixed brackets. One reason for this is that, by occupying the interocclusal space, precluding the contact between opponent teeth, the aligners prevent adequate intercuspation and consequently the achievement of ideal contact points, not only at treatment completion, but also during it (Djeu, Shelton \& Maganzini, 2005; Phan \& Ling, 2007; Papadimitriou et al, 2007).

Thus, the objective of this study was to comparatively evaluate the changes occurring in occlusal contact points over the first 6 months of orthodontic treatment with fixed brackets and esthetic aligners.

\section{Methodology}

This study was submitted to the Institutional Review Board of University \#\#\#\#\#\#\# and approved under number 3.384.099.

A parallel randomized clinical trial was conducted (Pereira, 2018; Koche, 2011), in which the participants were prospectively recruited and randomly divided into 2 groups by a draw performed by computer. A sample of 40 participants was selected for the groups: CAT ( $n=20$, esthetic aligners) and AF ( $n=20$, fixed appliance). Simple randomization was used to obtain homogeneity for the factors gender, age, amount of crowding (Little Index) and severity of malocclusion (PAR Index).

The inclusion criteria were: patients with Class I malocclusion, mild to moderate crowding (3-5 $\mathrm{mm}$ ) without need for tooth extraction, aged 15 to 30 years. The exclusion criteria were absence of permanent teeth, anterior open bite, crossbite or previous orthodontic treatment.

The recruited patients were informed about the study and inclusion in each sample group by a draw. Those who agreed to participate in the study signed an informed consent form. The patients were informed that the treatment would be performed for free, except for the initial documentation consisting of dental casts, photographs, radiographs and computed tomography of the jaws, requirements to conduct a study involving other variables to be investigated.

The occlusal contacts were recorded for the two study groups using an eight-micron thick carbon paper strip (AccuFilm - USA) in maximum intercuspation. The occlusal contacts were recorded with the patient seated in an appropriate chair, after receiving instructions on the mandibular movement to be performed (opening and closing in maximum intercuspation, applying pressure). Then, the researcher dried the occlusal surfaces with air, placed the carbon paper strips between the arches and asked the patient to close the mandible in the previously trained position. After this record, all identified contacts (Figure 1.A-B) were copied to an occlusogram that is part of the clinical form and counted. This procedure was performed in the following periods: before treatment onset (baseline) (T0), and during the first 6 months after placement, T1, T2, T3, T4, T5 and T6 after monthly maintenances.

Figure 1. Recording of contact points obtained in a patient with fixed appliance (A) and orthodontic aligner (B).
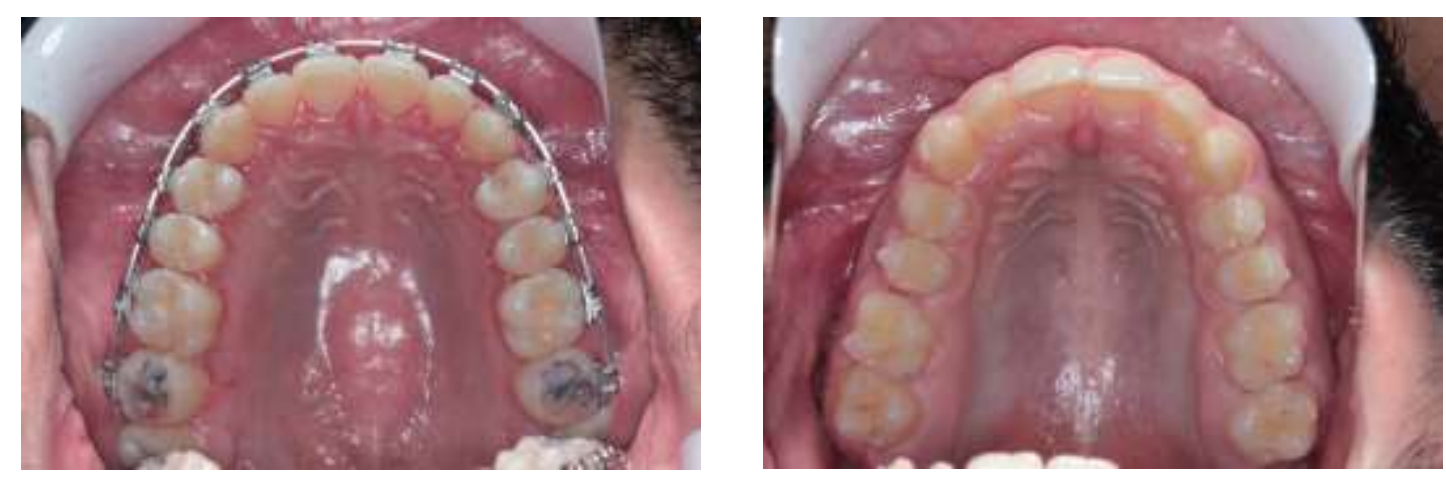

Source: Authors. 
At completion of 6 months of treatment, the sample had 17 patients in the aligners group (CAT) and 18 in the fixed appliance group (AF). Three patients in the CAT group and two in the AF group were excluded because they did not attend all evaluations.

\section{Statistical analysis}

A parametric test was applied to analyze data, since they presented normal distribution according to the Shapiro-Wilk test. Data for intragroup and intergroup analyses were assessed using the Anova test, at a significance level of $5 \%$. Statistical tests were performed using the Jamovi software (Jamovi Stats, Version 1.2, Sydney, Australia).

\section{Results}

Table 1 describes the mean of contact points for each group in the study periods.

Table 1 - Mean of contact point for each group descriptive results in the study periods.

\begin{tabular}{|c|c|c|c|c|c|}
\hline & APPLIANCE & $\mathbf{N}$ & MEAN & SD & SE \\
\hline \multirow[t]{2}{*}{ BASELINE } & CAT & 17 & 18.8 & 4.74 & 1.149 \\
\hline & $\mathrm{AF}$ & 18 & 22.3 & 5.99 & 1.412 \\
\hline \multirow[t]{2}{*}{$1^{\mathrm{ST}} \mathrm{MONTH}$} & CAT & 17 & 17.8 & 6.02 & 1.459 \\
\hline & $\mathrm{AF}$ & 18 & 16.6 & 5.27 & 1.243 \\
\hline \multirow[t]{2}{*}{$2^{\mathrm{ND}} \mathrm{MONTH}$} & CAT & 17 & 19.2 & 5.14 & 1.247 \\
\hline & $\mathrm{AF}$ & 18 & 21.7 & 3.38 & 796 \\
\hline \multirow[t]{2}{*}{$3^{\mathrm{RD}} \mathrm{MONTH}$} & CAT & 17 & 13.7 & 5.21 & 1.262 \\
\hline & $\mathrm{AF}$ & 18 & 17.7 & 5.40 & 1.273 \\
\hline \multirow[t]{2}{*}{$4^{\mathrm{TH}} \mathrm{MONTH}$} & CAT & 17 & 17.2 & 6.17 & 1.496 \\
\hline & $\mathrm{AF}$ & 18 & 18.9 & 5.31 & 1.252 \\
\hline \multirow[t]{2}{*}{$5^{\mathrm{TH}} \mathrm{MONTH}$} & CAT & 17 & 16.1 & 3.61 & 876 \\
\hline & $\mathrm{AF}$ & 18 & 19.6 & 5.33 & 1.256 \\
\hline \multirow[t]{2}{*}{$6^{\mathrm{TH}} \mathrm{MONTH}$} & CAT & 17 & 16.2 & 5.90 & 1.430 \\
\hline & $\mathrm{AF}$ & 18 & 19.8 & 6.03 & 1.422 \\
\hline
\end{tabular}

Source: Authors.

It is observed that, over the 6 months, both for fixed appliances and for aligners, there was a reduction in the number of contacts. However, patients with fixed appliances had a greater number of points (19.8) compared to those using aligners (16.2).

Table 2 describes the mean of contact points for individuals treated with fixed appliances. 
Table 2 - Mean of contact points for individuals treated with fixed appliance. ANOVA Test.

\begin{tabular}{|l|l|l|}
\hline TUKEY & Q & (P) \\
\hline Mean (1 to 2) & 4.8952 & $<0.05$ \\
\hline Mean (2 to 3) & 4.3304 & $<0.05$ \\
\hline Mean (3 to 4) & 3.3890 & ns \\
\hline Mean (4 to 5) & 1.0355 & ns \\
\hline Mean (5 to 6) & 0.5648 & ns \\
\hline Mean (6 to 7) & 0.1883 & ns \\
\hline
\end{tabular}

Source: Authors

There was statistically significant reduction between months 1 and 2, as well as between months 2 and 3 .

Similarly, Table 3 performs this comparison for individuals treated with esthetic aligners.

Table 3 - Mean of contact points for individuals treated with clear appliance. ANOVA Test.

\begin{tabular}{|l|l|l|}
\hline TUKEY & Q & (P) \\
\hline Mean (1 to 2) & 0.8357 & ns \\
\hline Mean (2 to 3) & 1.2289 & ns \\
\hline Mean (3 to 4) & 4.6208 & $<0.05$ \\
\hline Mean (4 to 5) & 2.9003 & ns \\
\hline Mean (5 to 6) & 0.9340 & ns \\
\hline Mean (6 to 7) & 0.0983 & ns \\
\hline
\end{tabular}

Source: Authors.

Only between months 3 and 4 there was statistically significant reduction in the number of interarch contact points observed.

Table 4 shows the intergroup comparison in each study period. 
Table 4 - Contact points intergroup comparision in each study period. ANOVA Test.

\begin{tabular}{|c|c|c|c|c|}
\hline & F & df1 & df2 & p \\
\hline BASELINE & 3.843 & 1 & 32.0 & 0.059 \\
\hline $1^{\mathrm{ST}}$ MONTH & 0.398 & 1 & 31.9 & 0.533 \\
\hline $2^{\mathrm{ND}}$ MONTH & 2.700 & 1 & 27.4 & 0.112 \\
\hline $3^{\mathrm{RD}}$ MONTH & 4.880 & 1 & 33.0 & 0.034 \\
\hline $4^{\mathrm{TH}}$ MONTH & 0.771 & 1 & 31.7 & 0.387 \\
\hline $5^{\mathrm{TH}}$ MONTH & 5.215 & 1 & 30.0 & 0.030 \\
\hline $6^{\mathrm{TH}}$ MONTH & 3.187 & 1 & 33.0 & 0.083 \\
\hline
\end{tabular}

Source: Authors.

It shows that the groups had significantly different mean contact points at the third and fifth months of treatment.

\section{Discussion}

The evaluation of occlusal contact points during treatment, though scarcely studied, is paramount to aid in the quality of orthodontic treatment, being a key factor to determine the functionality of occlusion as well as its stability (Oltramari et al, 2007; Haydar, Cier \& Saatçi, 1992).

Despite the growing demand for esthetic aligners, several studies have shown that the results obtained with the use of this appliance do not present similar quality as those obtained with fixed appliances (Phan \& Ling, 2007; Papadimitriou et al, 2018; Ke, Zhu \& Zhu, 2019). Despite achieving satisfactory alignment and leveling, a negative effect is observed on posterior occlusal contacts and occlusal relationships (Djeu, Shelton \& Maganzini, 2005; Kassas et al, 2013).

However, when performing intragroup analysis in the present study, although there were small variations in the means of occlusal contacts in both groups, their values remained very close. This demonstrates that the type of appliance did not significantly influence the occurrence of contact points during the first six months. These results agree with those observed by Wieczorek and Loster (Wieczorek \& Loster, 2015). When performing a comparative assessment of contact points between orthodontically treated and non-treated patients, the authors found no significant difference between groups.

Regardless of the group evaluated, there was a reduction in the number of contact points considering the period before treatment onset as reference. A similar pattern has been reported in different studies (Haydar, Cier \& Saatçi, 1992; Gazit \& Lieberman, 1985; Durbin \& Sadowsky, 1986), in which it was observed that the number of contact points was lower at completion of orthodontic treatment. However, during the retention period, there is functional accommodation of occlusion and again there is an increase in the number of contact points (Sultana, Yamada \& Hanada, 2002).

However, these results must be carefully interpreted. The similar number of contact points between the two techniques does not necessarily imply that the occlusion is similar. Several authors Djeu, Shelton \& Maganzini, 2005; Papadimitriou et al., 2018; Ke, Zhu \& Zhu, 2019; Grunheid, et al., 2016; Li, Wang \& Zhang, 2015) have found that orthodontic treatment with fixed appliances may produce more balanced contact points, which is one of the main difficulties faced by aligners. However, it should be noted that the period evaluated in this study corresponds to the alignment and leveling stage, thus different results can be expected at treatment completion. 
There was also variation in the mean occlusal contacts in the fixed appliance group in the first two months of treatment $(\mathrm{p}<0.05)$. Also, within the study period, there was a reduction in the number of contact points in relation to the pretreatment stage. The same observation was made by Haydar et al (Haydar, Cier \& Saatçi, 1992) ${ }^{5}$ who evaluated the contact points of 20 orthodontically treated patients with fixed braces and compared them with 10 individuals who had not undergone any orthodontic therapy and found a reduction in the total number of interocclusal contacts in individuals undergoing orthodontic therapy.

In the group of orthodontic aligners, this variation was only relevant from the second to the third month of treatment, showing that changes in the number and location of occlusal contacts were not relevant at the end of six months of observation. These data disagree with the literature, which states that the occlusal coverage promoted by aligners impairs the proper occlusal adjustment (Djeu, Shelton \& Maganzini, 2005; Ke, Zhu \& Zhu, 2019). The difference between the present results and those observed in the literature may be associated with the evaluated treatment time. Since in the present study this assessment was performed in the first 6 months of treatment, this change may not have occurred yet, since the literature considers the occlusion at treatment completion.

The intergroup analysis (Table 4) revealed difference in the mean values of contact points at the third and fifth months of treatment, yet at completion of six months this difference was no longer observed. Although these results are not as relevant as the intragroup analysis, i.e., the variation that occurred in each group, the groups had similar means of occlusal contacts at completion of the study period.

\section{Conclusion}

Based on the present results, it was observed that, despite the numerical changes in contact points in both approaches, these values did not present significant differences until the sixth month of treatment.

More details regarding changes in occlusal points after orthodontic treatment with clear aligners and fixed appliance is still needed.

\section{References}

Andrews, L. F. (1972). The keys to normal occlusion. American Journal of Orthodontics, 62, 296-309.

Angle, E. H. (1899). Classification of malocclusion. Dental Cosmos, 41, 248-264.

Azazipour, A., Weusmann, J., Mahmoodi, B., Peppas, D., Gerhold-Ay, A, Van Noorden, C. J. F., et al. (2015). Braces versus Invisalign®: gingival parameters and patients' satisfaction during treatment: a cross-section study. BMC Oral Health, 15 (69), 1-5.

Djeu, G., Shelton, C. \& Maganzini, A. (2005). Outcome assessment of Invisalign and traditional orthodontic treatment compared with the American Board of Orthodontics objective grading system. American Journal of Orthodontics and Dentofacial Orthopedics, 128 (3), $292-8$.

Durbin, D. S. \& Sadowsky, C. (1986). Changes in tooth contacts following orthodontic treatment. American Journal of Orthodontics and Dentofacial Orthopedics, 90 (5), 375-82.

Gazit, E. \& Lieberman, M. A. (1985). Occlusal contacts following orthodontic treatment: measured by a photoocclusion technique. The Angle Orthodontist, 55 (4), 316-20.

Grünheid, T., Gaalaas, S., Hamdan, H. \& Larson, B. E. (2016). Effect of clear aligner therapy on the buccolingual inclination of mandibular canines and the intercanine distance. The Angle Orthodontist, 86 (1), $10-6$.

Haydar, B., Cier, S. \& Saatçi, P. (1992). Occlusal contact changes after the active phase of orthodontic treatment. American Journal of Orthodontics and Dentofacial Orthopedics, 102 (1), 22-8.

Lim, W. H., Choi, B., Lee, J. Y. \& Ahn, S. J. (2014). Dentofacial characteristics in orthodontic patients with centric relation-maximum intercuspidation discrepancy. The Angle Orthodontist, 84 (6), 939-45.

Papadimitriou, A., Mousoulea, S., Gkantidis, N. \& Kloukos, D. (2018). Clinical effectiveness of Invisalign ${ }^{\circledR}$ orthodontic treatment: a systematic review. Progress in Orthodontics, 19 (1), 37.

Phan, X. \& Ling, P. H. (2007). Clinical limitations of Invisalign. Journal of Canadian Dental Association, 73 (3), $263-6$. 
Research, Society and Development, v. 10, n. 8, e51310817726, 2021

(CC BY 4.0) | ISSN 2525-3409 | DOI: http://dx.doi.org/10.33448/rsd-v10i8.17726

Roth, R. H. (1976). The maintenance system and occlusal dynamics. Dental Clinics of North America, 20, 761-788.

Kassas, W., Al-Jewair, T., Preston, C. B. \& Tabbaa, S. (2013). Assessment of Invisalign treatment outcomes using the ABO Model Grading System. Journal of World Federation of Orthodontics, 2 (2), 61-4

Ke, Y., Zhu, Y. \& Zhu, M. (2019). A comparison of treatment effectiveness between clear aligner and fixed appliance therapies. BMC Oral Health, 19 (1), 24.

Köche, J. C. (2016). Fundamentos de metodologia científica. Editora Vozes

Li, W., Wang, S. \& Zhang, Y. (2015). The effectiveness of the Invisalign appliance in extraction cases using the ABO model grading system: a multicenter randomized controlled trial. International Journal of Clinical and Experimental Medicine, 8 (5), 8276-82.

Pereira A. S. et al. (2018). Metodologia da pesquisa cientifica. [e-book]. Santa Maria. Ed. UAB/NTE/UFSM. https://repositorio.ufsm.br/bitstream/handle/1/15824/Lic_Computacao_Metodologia-Pesquisa-Cientifica.pdf?sequence=1.

Oltramari, P. V. P., Conti, A. C. C. F., Navarro, R. L., Almeida, M. R., Almeida-Pedrin, R. R. \& Ferreira, F. P. C. (2207). Importance of occlusion aspects in the completion of orthodontic treatment. Brazilian Dental Journal, 18 (1),7 8-82.

Sultana, M. H., Yamada, K. \& Hanada, K. (2002). Changes in occlusal force and occlusal contact area after active orthodontic treatment: a pilot study using pressure-sensitive sheets. Journal of Oral Rehabilitation, 29 (5), 484-91.

Wieczorek, A. \& Loster, J. E. (2015). Activity of the masticatory muscles and occlusal contacts in young adults with and without orthodontic treatment. BMC Oral Health, 15 (1), 116.

Watanabe-Kanno, G. \& Abrão, J. (2012). Study of the number of occlusal contacts in maximum intercuspidation before orthodontic treatment in subjects with Angle Class I and Classs II division 1 malocclusion. Dental Press Journal of Orthodontics, 17 (1), 138-47. 